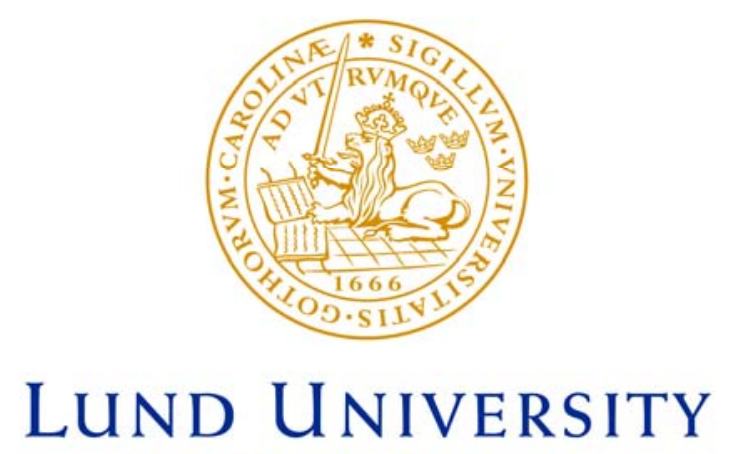

Faculty of Medicine

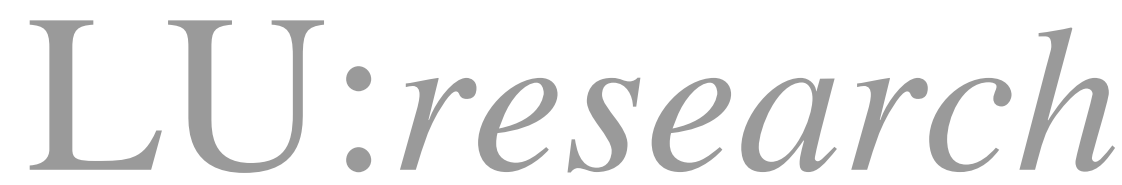

Institutional Repository of Lund University

This is an author produced version of a paper published in

BJOG : an international journal of obstetrics and gynaecology. This paper has been peer-reviewed but does not include the final publisher proof-corrections or journal pagination.

Citation for the published paper:

Herbst, A and Nilsson, C.

"Diagnosis of early preterm labour"

BJOG : an international journal of obstetrics and

gynaecology, 2006, Vol: 113, Issue: Supple 3, pp. 60-7.

http://dx.doi.org/10.1111/j.1471-0528.2006.01125.x

Access to the published version may require journal subscription.

Published with permission from: Blackwell Pub. 


\title{
Diagnosis of early preterm labour
}

\author{
Andreas Herbst*, Christer Nilsson \\ Department of Obstetrics and Gynaecology, Lund University Hospital, Sweden
}

\begin{abstract}
While preterm contractions occur almost as often extremely preterm as they do closer to term, birth due to spontaneous preterm labour before 27 weeks' gestation is rare, accounting for $0.05-0.7 \%$ of all births in different populations. Although the likelihood that uterine contractions before 27 weeks' gestation represent true preterm labour is low, the risk of adverse outcome in such cases is high. A correct diagnosis is important and a useful diagnostic test should have a high sensitivity. In most reports, only $30-40 \%$ of women hospitalised for spontaneous preterm labour experience a preterm birth, suggesting a low positive predictive value of clinical diagnosis based on uterine contractions and vaginal examination. Transvaginal ultrasonographic scanning (TVUSS) of cervical length has shown a high sensitivity for preterm birth, 90-100\% for preterm birth before 33-35 weeks, using a liberal cut-off at $30 \mathrm{~mm}$. Assessment of cervico-vaginal fetal fibronectin (FFN) levels has shown a sensitivity of about $80 \%$. Adding FFN assessment to TVUSS might contribute insignificantly to the prediction of preterm birth. In a retrospective study of 147 women with spontaneous preterm labour and intact membranes before 27 weeks in our Department, $61 \%$ of hospitalised women and $77 \%$ of women receiving tocolytic infusion therapy delivered before 32 weeks. Among 66 singleton pregnancies delivered before 32 weeks, at admission, 94\% either had an effaced or $\geq 2 \mathrm{~cm}$ dilated cervix (74\%), vaginal bleeding $(61 \%)$, or serum C-reactive protein (s-CRP) $>20(40 \%)$, whereas one of these findings only was present in $18 \%$ of women who delivered at later gestations. Among 132 women with symptoms of spontaneous preterm labour before 27 weeks not admitted for hospital care, only two $(1.5 \%)$ delivered before 32 weeks, not significantly higher than for all other women (0.6\%). Although TVUSS may be useful when the diagnosis of spontaneous preterm labour is in doubt, the main predicament in early spontaneous preterm labour may not be to predict preterm birth, but to prevent it, since many women appear in advanced labour or with manifest chorioamnionitis.
\end{abstract}

\section{INTRODUCTION}

Spontaneous preterm labour is usually defined as labour before 37 completed weeks of gestation. It is at very early gestational ages that the consequences of preterm birth are often serious. This article will focus on very early preterm birth, particularly before 27 weeks' gestation, when mortality is considerable and morbidity expected.

\section{INCIDENCE OF EXTREMELY PRETERM LABOUR}

Spontaneous preterm birth is a rare event in the early preterm period, though the rate varies between studies, due to different populations and classifications. In an American study, the rate of preterm birth before 27 weeks due to spontaneous preterm labour was $0.7 \%$ of all births ( $36 \%$ of these early births) $)^{1}$. In a population based study from northern Sweden, singleton preterm births due to spontaneous preterm labour represented $0.05 \%$ of all births and $20 \%$ of these early births ${ }^{2}$. In the latter study, preterm birth before 27 weeks was less often due to spontaneous preterm labour (RR 0.6;

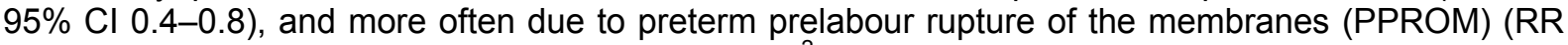
$4.1 ; 95 \% \mathrm{Cl} 3.1-5.6)$, compared with in weeks $32-36^{2}$.

Despite the fact that uterine activity normally increases with advancing gestational age ${ }^{3}$, pregnant women frequently seek medical advice for preterm contractions at early gestation. As early preterm birth is rare, the likelihood that uterine contractions in the early preterm period represent true spontaneous preterm labour is $l^{4}{ }^{4}$. Since the risk of adverse outcome is high with true preterm labour, and decreases significantly with advancing gestational age ${ }^{2}$, corticosteroid treatment ${ }^{5}$, and referral to a perinatal centre ${ }^{6}$, a correct diagnosis of early preterm labour is important. 


\section{SYMPTOMS OF SPONTANEOUS PRETERM LABOUR}

The characteristics of uterine contractions and the presence of associated symptoms may provide clues as to whether preterm birth threatens. Regular painful uterine contractions of sudden onset are probably more likely to represent spontaneous preterm labour than a longer period of irregular contractions. In a study with prospective monitoring of uterine activity, women who went into spontaneous preterm labour had no measurable increase in uterine activity or subjective symptoms until the day labour started ${ }^{7}$. In other prospective studies a high uterine activity has been associated with later spontaneous preterm labour. A maximum evening contraction rate of $>4$ per hour in weeks 22-28 was associated with a threefold risk of preterm birth before 35 gestational weeks ${ }^{8}$. In another study, >6 contractions per hour on one occasion in weeks 28-32 weeks identified 12 of 16 women who later gave birth preterm (sensitivity $75 \%)^{9}$. A sensitivity of $75 \%$ for predicting delivery within 6 days was also achieved using power density spectrum analysis of electromyographic activity during contractions in women with spontaneous preterm contractions ${ }^{10}$.

Uterine contractions are not the only symptom of impending spontaneous preterm birth. Women may present with menstrual cramps, backache, pelvic pressure, vaginal discharge, urinary frequency or diarrhea,11. The presence of vaginal bleeding increases the risk of preterm birth ${ }^{12}$, and has been associated with intrauterine infection ${ }^{13}$.

\section{SIGNS OF SPONTANEOUS PRETERM LABOUR}

An effaced or dilated cervix confirms the diagnosis of spontaneous preterm labour. McWeeney et al. assessed the risk of preterm birth in 3,496 women admitted for spontaneous preterm labour in relation to cervical dilation after stabilisation with tocolytic treatment ${ }^{14}$. At a cervical dilation of $0,1,2$, 3 , and $4 \mathrm{~cm}$, the risk of preterm birth before 28 weeks was $2.5 \%, 4 \%, 17 \%, 29 \%$ and $75 \%$, respectively. The estimated risk of preterm birth was higher the earlier in gestation a woman with a defined cervical dilatation was admitted (Figure 1) ${ }^{14}$.

Digital examination of the cervix may not be sufficient to rule out true spontaneous preterm labour, and additional diagnostic methods have been suggested. Considering the consequences of preterm birth, the sensitivity of such a test should be high, especially in early spontaneous preterm labour, and the positive predictive value (PPV) reasonable, so that a disproportionate number of women are not hospitalised. A few studies have compared the diagnostic value of digital and TVUSS assessment of the cervix in spontaneous preterm labour ${ }^{15-19}$. lams et al. reported that a digital examination finding of dilatation $\geq 2 \mathrm{~cm}$ had a sensitivity of $62 \%$ in predicting preterm birth (PPV $40 \%$ ), effacement $\geq 50 \%$ a sensitivity of $83 \%$ (PPV $48 \%$ ), and cervical length $<30 \mathrm{~mm}$ using TVUSS, a sensitivity of $100 \%$ (PPV $55 \%)^{15}$. Önderglou et al. found that palpated dilatation $>2 \mathrm{~cm}$ had a sensitivity of $66 \%$ (PPV $57 \%$ ), effacement $>40 \%$ a sensitivity of $62 \%$ (PPV $52 \%$ ), and cervical length $<29 \mathrm{~mm}$ at transperineal ultrasonongraphy, a sensitivity of $78 \%$ (PPV $71 \%)^{16}$. In two other studies, the risk of preterm birth increased with high Bishop scores as well as with short cervical length on TVUSS, but the confidence intervals overlapped ${ }^{17,18}$, and in one report cervical length and funnelling were associated with preterm birth while digital assessment was not ${ }^{19}$.

\section{CERVICAL ASSESSMENT BY ULTRASONOGRAPHY}

The inter-observer reliability for estimation of cervical length is higher for TVUSS than for digital assessment $\mathrm{t}^{20}$. It provides additional information, since only the vaginal portion of the cervix is palpable when the cervix is closed, and dilation of the internal cervical os is difficult to detect by palpation. The mean cervical length decreases from about $40 \mathrm{~mm}$ at 20 gestational weeks to about $34 \mathrm{~mm}$ in week 34 , with corresponding lower statistical limits (-2 SD) of $29 \mathrm{~mm}$ and $20 \mathrm{~mm}$, respectively ${ }^{21}$. A short cervix is a risk factor for preterm birth, and screening for cervical length in mid second trimester has been evaluated in high risk pregnancies, and as a population screening ${ }^{22}$. In a recent report including 39,284 women screened in gestational weeks $22-24$, cervical length was normally distributed (mean $36 \mathrm{~mm}$ ), and the risk of preterm birth before 32 weeks increased progressively with decreasing cervical length below $16 \mathrm{~mm}^{23}$. About half of these early deliveries could be predicted by TVUSS alone when a false positive rate of $5-10 \%$ was accepted. A dilation of the internal cervical os, "funnelling", is usually reflected by a decreased cervical length, but may be an additional independent risk factor for early preterm birth ${ }^{24,25}$, as may a minor cervical canal dilation $(2-4 \mathrm{~mm})^{26}$. 
Table 1 presents studies of cervical length in women with spontaneous preterm labour ${ }^{15-19,27-41}$. With $30-32 \mathrm{~mm}$ as cut-off, the sensitivity was $81-100 \%$ for predicting delivery before $36-37$ gestational weeks and 88-100\% for preterm birth before 34-35 weeks, with positive predictive values of $54-69 \%$ and $20-64 \%$, respectively. Most studies excluded women with a cervical dilation $\geq 3 \mathrm{~cm}$, since further diagnostic procedures were considered unnecessary in these cases. Some studies only included women with cervical shortening or dilation, ${ }^{15-19,28,29,31,32}$ eliminating the possibility of identifying cases of possible preterm birth without palpable changes. Two trials only included women after successful tocolysis, ${ }^{15,28}$ which might be considered too late to evaluate a diagnostic test, and one study excluded birth within 24 hours ${ }^{30}$. Although no study specifically assessed very early spontaneous preterm labour, some of the studies using 30-32 mm as a cut-off assessed patients admitted before 34 or 35 gestational weeks ${ }^{29,31,32,34}$, and one study presented a sub-analysis of spontaneous preterm labour before 32 weeks' gestation ${ }^{33}$. The sensitivity for predicting preterm birth $(81-100 \%)$ was similar to studies that included spontaneous preterm labour at later gestations.

Cervical length is usually assessed between contractions but measurement of cervical length during a uterine contraction may be at least as good a predictor of preterm birth as measurement of the length at rest ${ }^{42}$. Funnelling has also been evaluated as predictor of preterm birth in women with spontaneous preterm labour, with a reported sensitivity of $77-100 \%{ }^{9,43}$. Other authors have concluded that funnelling is not an independent predictor of preterm birth in spontaneous preterm labour ${ }^{29,31}$.

\section{LABORATORY TESTS}

An elevated white blood cell count and serum levels of C-reactive protein (CRP) have been associated with preterm birth in women in spontaneously preterm labour ${ }^{12,44,45}$. A CRP level of 15 $\mathrm{mg} / \mathrm{L}$ represented the $90^{\text {th }}$ percentile in a pregnant population ${ }^{46}$. An elevated CRP in early pregnancy has also been associated with later preterm birth ${ }^{47}$. A high CRP may reflect infection, but also labour, since CRP also rises during labour without signs of infection ${ }^{48,49}$.

Fetal fibronectin (FFN) is a glycoprotein found in high concentrations in the placenta and amniotic fluid. FFN is detectable in the cervico-vaginal secretion in about $4 \%$ of pregnant women after 20 gestational weeks, possibly reflecting transudation of amniotic fluid or disruption of the chorio-decidual interface ${ }^{50}$. Honest et al. conducted a meta-analysis of the predictive value of FFN for preterm birth in women in spontaneous preterm labour ${ }^{51}$. In eight studies, the sensitivity to predict preterm birth before 34 weeks ranged from 21-94\% (median 80\%), whereas the PPV ranged from 12-79\% (median 48\%). The sensitivity was higher at 50-100\% (median 86\%) for birth within 7-10 days (17 studies).

Elevated levels of interleukin 6 (IL-6) in the amniotic fluid and in cervical secretion have been shown to predict preterm birth in women in spontaneous preterm labour ${ }^{50,52}$. In one study, a cervical IL-6 level above $20 \mathrm{pg} / \mathrm{mL}$ had a sensitivity of $100 \%$ (PPV 47\%) for predicting birth before 34 weeks $^{52}$. Elevated levels of IL-6 in cervical fluid has been associated with intraamniotic inflammation ${ }^{53}$, but also with term and spontaneous preterm labour without signs of infection ${ }^{49}$.

\section{TVUSS COMBINED WITH FFN}

The potential to improve the diagnosis of spontaneous preterm labour by combining TVUSS with the assessment of cervicovaginal FFN has been evaluated. ${ }^{17,31,33,34,35,38,53}$ Hincz et al. reported a sensitivity of $86 \%$ (PPV 63\%) for birth within 4 weeks of either a cervical length $<21 \mathrm{~mm}$ or a cervical length of $21-30 \mathrm{~mm}+\mathrm{FFN}>50 \mathrm{ng} / \mathrm{mL}^{31}$. Gomez et al. reported a sensitivity of $89 \%$ (PPV 30\%) for spontaneous preterm labour and preterm birth before 32 weeks with a cervical length $<15 \mathrm{~mm}$, or FFN $>50 \mathrm{ng} / \mathrm{mL}^{33}$. Schmitz et al. reported a sensitivity of $90 \%$ (PPV 20\%) for preterm birth before 35 weeks for a cervical length $\leq 15 \mathrm{~mm}$ or a length of $16-30 \mathrm{~mm}+\mathrm{FFN}>50 \mathrm{ng} / \mathrm{mL}{ }^{34}$ While some authors found that the combination improved the diagnostic efficiency over TVUSS ${ }^{17,38}$, others found TVUSS alone to be equally efficient ${ }^{35,53}$. 


\section{LABOUR BEFORE 27 GESTATIONAL WEEKS: A HOSPITAL-BASED STUDY}

In most reports, only $30-40 \%$ of women hospitalised for spontaneous preterm labour experience preterm birth (Table 1), suggesting a low PPV of the clinical diagnosis. Few studies have specifically focused on very early spontaneous preterm labour, the period when a correct diagnosis matters most. A retrospective study was undertaken to assess the rate of preterm birth in women treated for spontaneous preterm labour before 27 weeks' gestation, and to study the associations between symptoms and signs at admission and very early preterm birth.

\section{METHODS}

The study included all women admitted to Lund University Hospital for spontaneous preterm labour with intact membranes at admission, between January 2000 and August 2005. The hospital is a referral unit for Southern Sweden, an area with approximately 16,000 deliveries each year. During the study period, cervical assessment by TVUSS was optional, but not mandatory, for a diagnosis of spontaneous preterm labour; FFN was not measured. The medical files were assessed for all inpatients with a diagnosis of spontaneous preterm contractions or threatened spontaneous preterm labour (ICD-10: O47) or PPROM (ICD-10: O42). Only women with intact membranes at admission were included. Recorded data included symptoms and findings at admission, tocolytic and other medical treatment, complications, latency period from admission to delivery, and gestational age at birth. For statistical comparisons, Fisher's exact test was used for categorical variables and MannWhitney test for continuous variables.

\section{RESULTS}

In total, 222 women received hospital care for spontaneous preterm labour before 27 weeks' gestation during the study period; $149(67 \%)$ with intact membranes at admission. The median gestational age at admission was $24+4$ weeks. Two women were discharged undelivered and could not be traced. Of the remaining 147 women, $110(75 \%)$ delivered preterm; $90(61 \%)$ before 32 weeks and $20(14 \%)$ between 32 and 36 weeks. Of 32 multiple pregnancies, 24 delivered before 32 weeks and eight in weeks 33-36.

Of 115 singleton pregnancies, 66 (57\%) were delivered before 32 weeks (all before 30 weeks) spontaneously or due to complications associated with spontaneous preterm labour (chorioamnionitis, abruption). Thirteen women (11\%) delivered preterm after 32 weeks (all after 33 weeks), and $36(31 \%)$ gave birth at term.

Of the 115 singleton pregnancies with intact membranes, 65 had contractions requiring tocolytic infusion therapy with atosiban $(n=52)$, terbutaline $(n=11)$ or both $(n=2)$. Of these women, $50(77 \%)$ delivered before 32 weeks, six gave birth in weeks $33-36$ and nine at term. The median latency period from admission to delivery for those receiving tocolytic treatment and being delivered before 32 weeks ("true spontaneous preterm labour") was 5 days (range 0-32). For 34 women, tocolytic infusion therapy was considered unnecessary, and none of them delivered before 32 weeks. They had a short median hospital stay of 2 days. In 14 cases tocolysis was considered contraindicated due to suspected chorioamnionitis, abruption or both, and two cases were considered too late to treat. These 16 women all delivered before 32 weeks.

The symptoms, signs, and CRP-level at admission in relation to the rate of early preterm birth are presented in Table 2. Among 66 women delivered before 32 weeks, $62(94 \%)$ had an effaced or $\geq 2$ $\mathrm{cm}$ dilated cervix or bulging membranes $(74 \%)$, vaginal bleeding $(61 \%)$, or a CRP-level above 20 $(40 \%)$, whereas one of these findings was present in $18 \%$ of women who delivered later. The four women without any of these signs who delivered before 32 weeks all had a cervical length on TVUSS below $20 \mathrm{~mm}$ (range 10-18 $\mathrm{mm}$ ). 


\section{PRETERM CONTRACTIONS BEFORE 27 WEEKS' GESTATION: A POPULATION-BASED STUDY}

A second study was undertaken to evaluate if there was an under-diagnosis of early spontaneous preterm labour which could indicate the necessity for additional diagnostic methods. In the area studied, routine pregnancy care was provided by midwives at antenatal clinics. During office hours women with complaints could present to these units and were sent to the hospital if an obstetric opinion was required. Women with acute symptoms could also present directly at the hospital, which was the only option during non-office hours.

\section{METHODS}

The rate of spontaneous preterm birth (starting with spontaneous preterm labour or PPROM), during June 2001 to August 2005 at Lund University Hospital was assessed for women living in the primary uptake area, and was compared for women with and without registered outpatient visits for preterm contractions during January 2001 to August 2005. The medical files of women with registered outpatient visits or hospital care for spontaneous preterm labour during gestational weeks 22-27 were analysed. For patients with more than one visit, only the first visit was considered. Fisher's exact test was used to analyse differences between groups.

\section{RESULTS}

Preterm birth before 37,32 and 27 gestational weeks occurred in $6.7 \%, 0.95 \%$ and $0.24 \%$ of the population, and spontaneous preterm birth in $4.6 \%, 0.54 \%$ and $0.12 \%$, respectively. The rates of spontaneous preterm birth for women with and without previous visits for preterm contractions are shown in Table 3.

In total, 503 of 11,406 women $(4.4 \%)$ had registered outpatient hospital visits for preterm contractions. The rate of spontaneous preterm birth among these women was low (7.6\%), and only significantly increased among those with a first visit in the late preterm period. Only four (1.3\%) of 306 women with previous outpatient visits for preterm contractions delivered spontaneously before 32 weeks, a rate not significantly higher than for other women. Only $7.2 \%$ of women with spontaneous preterm birth had a previous outpatient visit for preterm contractions.

Spontaneous preterm labour between 22 and 26 gestational weeks was studied more closely. In this gestational period, 33 women had been admitted for hospital care due to spontaneous preterm labour, and 132 women had outpatient visits with a diagnosis of preterm contractions, but were sent home. In three of 132 outpatient visits the diagnosis of preterm contractions had been given without documented symptoms. In nine cases the files were missing or contained no information about the visit. Six women had received hospital care for spontaneous preterm labour before the outpatient visit. Among the remaining 113 outpatient women with documented symptoms, 93 came for current contractions (two also had bleeding, one vaginal discharge, five a sense of vaginal pressure, and one symptoms of cystitis), and six came for other reasons but reported contractions as well. The main reason for 14 visits was an appeal for sick-leave from work due to contractions.

Among the 113 women with verified outpatient visits for preterm contractions, a digital vaginal examination was performed in $70(62 \%)$; the cervix was assessed to be $\geq 2 \mathrm{~cm}$ long or unaffected in 67 , and to be closed or open for less than $1.5 \mathrm{~cm}$ in all. In nine women $(8 \%)$ only a speculum examination was done, and the cervix was considered to be unchanged in all women. Cervical length was measured by TVUSS in 12 women (11\%), and was < $20 \mathrm{~mm}$ in one, and $20-29 \mathrm{~mm}$ in two. In 26 patients (including the 14 sick-leave cases) no examination was performed.

Of the 113 outpatients, $15(13 \%)$ delivered preterm (eight spontaneously). Only two delivered before 32 weeks, one classified as a spontaneous preterm birth, since the woman had contractions and PPROM before being delivered by Caesarean section for placental abruption.

Of the 33 women admitted for hospital care at the first visit, $18(55 \%)$ delivered preterm (12 spontaneously); 11 before 32 weeks (eight spontaneously). Only seven women received tocolytic infusion therapy, six of whom delivered preterm, all before 32 weeks (five spontaneously). 


\section{CONCLUSIONS}

In the very preterm period, most cases of true spontaneous preterm labour may be identified by vaginal bleeding or a dilated cervix on vaginal examination. A high maternal serum CRP level, often reflecting chorioamnionitis, is also common, and should induce hospital admission. In doubtful cases, measurement of the cervical length by TVUSS is a useful adjunct. If cervical length is more than 30 $\mathrm{mm}$, preterm birth is so unlikely that it is reasonable to send the patient home, provided no other signs of complications are present. It is doubtful whether additional predictive markers for preterm birth are needed in symptomatic women. In contrast, a problem in early spontaneous preterm labour is that many women appear in advanced labour or with manifest chorioamnionitis. In order to decrease the rate of very early preterm birth, we must direct our attention to the possibility of screening and to preventative measures.

\section{References}

1. Mercer B, Miluzzi Collin M. Periviable birth at 20 to 26 weeks of gestation: Proximate causes, previous obstetric history and recurrence risk. Am J Obstet Gynecol 2005;193:1175-1180.

2. Holmgren $P \AA \AA$, Högberg $U$. The very preterm infant - a population based study. Acta Obstet Gynecol Scand 2001;80:525-531.

3. Moore TR, lams JD, Creasy RK, et al. Diurnal and gestational patterns of uterine activity in normal human pregnancy. Obstet Gynecol 1994;83:517-523.

4. Nicholson W, Croughan-Minihane M, Posner S, Washington AE, Kilpatrick SK. Preterm delivery in patients admitted with preterm labor: a prediction study. J Matern Fetal Med 2001;10:102-106.

5. Finnström $\mathrm{O}$, Olausson $\mathrm{PO}$, Sedin $\mathrm{G}$, et al. The Swedish national prospective study on extremely low birthweight (ELBW) infants. Incidence, mortality, morbidity and survival in relation to level of care. Acta Pediatr 1997;86:503-511.

6. Crowley P. Prophylactical corticosteroids for preterm birth. Cochrane Database Syst Rev 2000:CD 000065.

7. lams JD, Johnson FF, Parker M. A prospective evaluation of the signs and symptoms of preterm labor. Obstet Gynecol 1994;84:227-230.

8. lams JD, Newman RB, Thom EA, et al. Frequency of uterine contractions and the risk of spontaneous preterm delivery. N Engl J Med 2002;346:250-255.

9. Main DM, Katz M, Chiu G, Campion S, Gabbe SG. Intermittent weekly contraction monitoring to predict preterm labor in low-risk women: a blinded study. Obstet Gynecol 1988;72:757-760.

10. Maner LM, Garfield RE, Maul H, Olson G, Saade G. Predicting term and preterm delivery with transabdominal uterine electromyography. Obstet Gynecol 2003;101:1254-1260.

11. Katz M, Goodyear K, Creasy RK. Early signs and symptoms of preterm labor. Am J Obstet Gynecol 1990;162:1150-1153.

12. Macones GA, Segel SY, Stamilio DM, Morgan MA. Prediction of delivery among women with early preterm labor by clinical characteristics alone. Am J Obstet Gynecol 1999;181:1414-1418.

13. Gomez R, Romero R, Nien JK, et al. Idiopathic vaginal bleeding during pregnancy as the only clinical manifestation of intrauterine infection. J Matern Fetal Neonatal Med 2005;18:31-37.

14. McWeeney D, Miller R, Rhea D, Stanziano G. Probability of prematurity by cervical dilatation and gestational age at preterm labor. Obstet Gynecol 2006;107(4 Suppl):31S.

15. lams JD, Paraskos J, Landon MB, Teteris JN, Johnson FF. Cervical sonography in preterm labor. Obstet Gynecol 1994;84:40-46.

16. Önderglou LS. Digital examination and transperineal ultrasonographic measurement of cervical length to assess risk of preterm delivery. Int J Gynecol Obstet 1997;59:223-228.

17. Tekesin I, Hellmeyer L, Heller G, Römer A, Kühnert M, Schmidt S. Evaluation of quantitative ultrasound tissue characterization of the cervix and cervical length in the prediction of premature delivery for patients with spontaneous preterm labor. Am J Obstet Gynecol 2003;189:532-539. 
18. Volumenie J-L, Luton D, De Sprilet M, Sibony O, Blot P, Oury J-F. Ultrasonographic cervical length measurement is not a better predictor of preterm delivery than digital examination in a population of patients with idiopathic preterm labor. Eur J Obstet Gynecol Reprod Biol 2004;117:33-37.

19. Gomez R, Galasso M, Romero R, Mazor M, Sorokin Y, Goncalves L, Treadwell M. Ultrasonographic examination of the uterine cervix is better than cervical digital examination as a predictor of the likelihood of premature delivery in patients with preterm labor and intact membranes. Am J Obstet Gynecol 1994;171:956-964.

20. Goldberg J, Newman RB, Rust PF. Interobserver reliability of digital and endovaginal ultrasonographic cervical length measurements. Am J Obstet Gynecol 1997;177:853-858.

21. Hoesli IM, Strutas D, Tercanli S, Holzgreve W. Charts for cervical length in singleton pregnancy. Int J Gynaecol Obstet 2003;82:161-165.

22. Antsaklis A, Daskalakis G. Ultrasonic measurements of the cervix and preterm labor. Ultrasound Rev Obstet Gynecol 2004;4:93-102.

23. To MS, Skentou CA, Royston $\mathrm{P}, \mathrm{Yu} \mathrm{CKH}$, Nicolaides $\mathrm{KH}$. Prediction of patient-specific risk of early preterm delivery using maternal history and sonographic measurement cervical length: a population-based prospective study. Ultrasound Obstet Gynecol 2006; 27:362-367.

24. De Carvalho MHB, Bittar RE, De Lourdes Brizot M, Bicudo C, Zugaib M. Prediction of preterm delivery in the second trimester. Obstet Gynecol 2005;105:532-536.

25. Rust OA, Atlas RO, Kimmel S, Roberts WE, Hess LW. Does the presence of a funnel increase the risk of adverse perinatal outcome in a patient with a short cervix? Am J Obstet Gynecol 2005;192:1060-1066.

26. Yost NP, Owen J, Berghella V, MacPherson C et al. Second-trimester cervical sonography: features other than cervical length to predict spontaneous preterm birth. Obstet Gynecol 2004;103:457-462.

27. Murakawa H, Utumi T, Hasegawa I, Tanaka K, Fuzimori R. Evaluation of threatened preterm delivery by transvaginal ultrasonographic measurement of cervical length. Obstet Gynecol 1993;82:829-832.

28. Cetin M, Cetin A. The role of transvaginal sonography in predicting recurrent preterm labour in patients with intact membranes. Eur J Obstet Gynecol Reprod Biol 1997;74:7-11.

29. Crane JM, Van den Hof M, Armson BA, Liston R. Transvaginal ultrasound in the prediction of preterm delivery: singleton and twin gestations. Obstet Gynecol 1997;90:357-363.

30. Vendittelli F, Mamelle N, Munoz F, Janky E. Transvaginal ultrasonography of the uterine cervix in hospitalized women with preterm labor. Int J Gynaecol Obstet 2001;72:117-25.

31. Hincz P, Wilczynski J, Kozarzewski M, Szaflik K. Two-step test: the combined use of fetal fibronectin and sonographic examination of the uterine cervix for prediction of preterm delivery in symptomatic patients. Acta Obstet Gynecol Scand 2002;81:58-63.

32. Daskalakis G, Thomakos N, Hatziioannou L, Mesogitis S, Papantoniou N, Antsaklis A. Cervical assessment in women with threatened preterm labor. J Matern Fetal Neonatal Med 2005;17:30912.

33. Gomez R, Romero R, Medina L, et al. Cervicovaginal fibronectin improves the prediction of preterm delivery based on sonographic cervical length in patients with preterm uterine contractions and intact membranes. Am J Obstet Gynecol 2005;192:350-359.

34. Schmitz Schmitz T, Maillard F, et al. Selective use of fetal fibronectin detection after cervical length measurement to predict spontaneous preterm delivery in women with preterm labor. $A m \mathrm{~J}$ Obstet Gynecol 2006;194:138-143.

35. Rozenberg P, Goffinet F, Malagrida $L$ et al. Evaluating the risk of preterm delivery: a comparison of fetal fibronectin and transvaginal ultrasonographic measurement of cervical length. Am J Obstet Gynecol 1997;176:196-199. 
36. Fuchs I, Tsoi E, Henrich W, Dudenhausen JW, Nicolaides KH. Sonographic measurement of cervical length in twin pregnancies in threatened preterm labor. Ultrasound Obstet Gynecol 2004;23:42-45.

37. Tsoi E, Fuchs IB, Rane S, Geerts L, Nicolaides KH. Sonographic measurement of cervical length in threatened preterm labor in singleton pregnancies with intact membranes. Ultrasound Obstet Gynecol 2005;25:353-356.

38. Rizzo G, Capponi A, Arduini D, Lorido C, Romanini C. The value of fetal fibronectin in cervical and vaginal secretions and of ultrasonographic examination of the uterine cervix in predicting premature delivery for patients with preterm labor and intact membranes. Am J Obstet Gynecol 1996;175:1146-1151.

39. Fuchs IB, Henrich W, Osthues K, Dudenhausen JW. Sonographic cervical length in singleton pregnancies with intact membranes presenting with threatened preterm labor. Ultrasound Obstet Gynecol 2004;24:554-557.

40. Tsoi E, Akmal S, Rane S, Otigbah C, Nicolaides $\mathrm{KH}$. Ultrasound assessment of cervical length in threatened preterm labor. Ultrasound Obstet Gynecol 2003;21:552-555.

41. Tsoi E, Geerts L, Jeffery B, Odendaal HJ, Nicolaides KH. Sonographic cervical length in threatened preterm labor in a South African population. Ultrasound Obstet Gynecol 2004;24:644646.

42. Jenkins SM, Kurtzman JT, Osann K. Dynamic cervical change: is real-time sonographic cervical shortening predictive of preterm delivery in patients with symptoms of preterm labor? Ultrasound Obstet Gynecol 2006;27:373-376.

43. Timor-Tritsch IE, Boozarjomehri F, Masakowski Y, Monteagudo A, Chao CR. Can a "snapshot" sagittal view of the cervix by transvaginal ultrasonography predict active preterm labor? Am J Obstet Gynecol 1996;174:990-995.

44. Watts DH, Krohn MA, Hillier SL, Wener MH, Kiviat NB, Eschenbach DA. Characteristics of women in preterm labor associated with elevated C-reactive protein levels. Obstet Gynecol 1993;82:509_ 514.

45. Vogel I, Grove J, Thorsen P, Moestrup SK, Uldbjerg N, Moller HJ. Preterm delivery predicted by soluble CD163 and CRP in women with symptoms of preterm delivery. BJOG 2005;112:737-742.

46. Watts $\mathrm{DH}, \mathrm{Krohn} \mathrm{MA}$, Wener MH, Eschenbach DA. C-reactive protein in normal pregnancy. Obstet Gynecol 1991;77:176-180.

47. Hvilsom GB, Thorsen P, Jeune B, Bakketeig LS. C-reactive protein: a serological marker for preterm delivery? Acta Obstet Gynecol Scand 2002:81:424-429.

48. de Villiers WJ, Louw JP, Strachan AF, Etsebeth SM, Shephard EG, de Beer FC. C-reactive protein and serum amyloid A protein in pregnancy and labour. Br J Obstet Gynaecol 1990;97:725730.

49. Abelin-Törnblom S, Klimaviciute A, Byström B, Chromek M, Brauner A, Ekman-Ordeberg G. Noninfected preterm parturition is related to increased concentrations of IL-6, IL-8, and MCP-1 in human cervix. Reprod Biol Endocrinol 2005;25:39.

50. Vogel I, Thorsen P, Curry A, Sandager P, Uldbjerg N. Biomarkers for the prediction of preterm delivery. Acta Obstet Gynecol Scand 2005;84:516-525.

51. Honest H, Bachmann LM, Gupta JK, Kleijnen J, Khan KS. Accuracy of cervicovaginal fetal fibronectin test in predicting risk of spontaneous preterm birth: systematic review. BMJ 2002;325:301-311.

52. Holst RM, Mattsby-Baltzer I, Wennerholm UB, Hagberg H, Jacobsson B. Interleukin-6 and interleukin-8 in cervical fluid in a population of Swedish women in preterm labor: relationship to microbial invasion of the amniotic fluid, intra-amniotic inflammation, and preterm delivery. Acta Obstet Gynecol Scand 2005;84:551-557.

53. Tsoi E, Akmal S, Geerts L, Jeffery B, Nicolaides KH. Sonographic measurement of cervical length and fetal fibronectin testing in threatened preterm labor. Ultrasound Obstet Gynecol 2006;27:368372. 
Figure 1. Probability of preterm delivery before 35 weeks in women hospitalised for preterm labour, according to gestational age at admission and cervical dilation after stabilisation, estimated by logistic regression (adapted from McWeeney et al. $2006^{14}$ ).

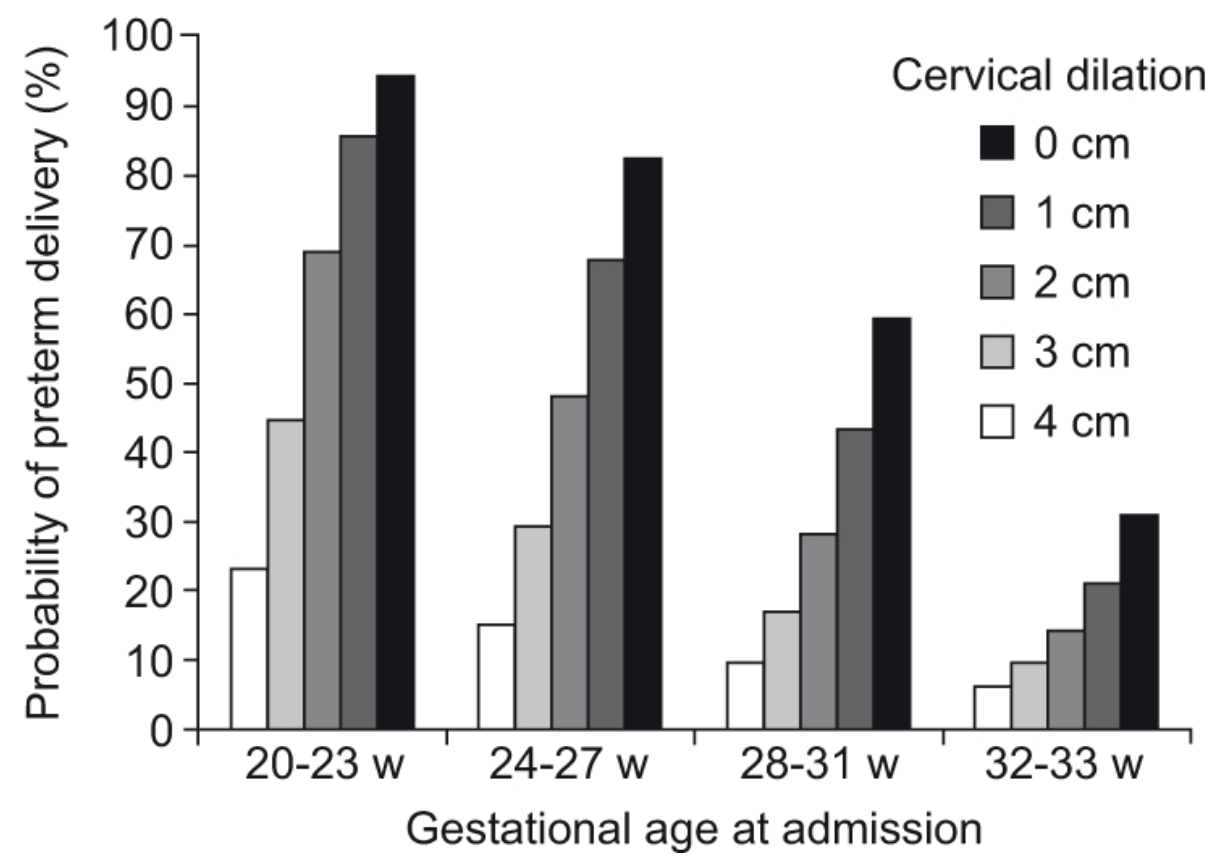


Table 1. Studies of cervical length measured by transvaginal or transperineal (Önderglou et al. ${ }^{16}$ ) ultrasonography to predict preterm birth in women hospitalised for preterm labour. Only the originally presented cut-off level with the highest sensitivity is presented here. None of the studies included women with ruptured membranes

\begin{tabular}{|c|c|c|c|c|c|c|c|c|c|c|}
\hline $\begin{array}{l}\text { Authors, year of } \\
\text { publication, } \underline{\text { ref }}\end{array}$ & $\underline{\mathrm{N}}$ & $\frac{\text { Cut-off }}{\text { below }}$ & at inclusion & Main inclusion criteria* & Main exclusion criteria ${ }^{* *}$ & $\frac{\text { Ourcome (birth }}{\underline{\text { or spont. birth) }}}$ & $\frac{\text { Outcome }}{\text { rate }}$ & $\underline{\text { Sensi- }}$ & NPV & $\underline{\text { PPV }}$ \\
\hline Murakawa et al., $1993^{27}$ & 32 & $30 \mathrm{~mm}$ & $25-35$ & A,B & & $<37$ weeks & $34 \%$ & $100 \%$ & $100 \%$ & $65 \%$ \\
\hline Iams et al., $1994^{15}$ & 60 & $30 \mathrm{~mm}$ & $24-35$ & B,C,D,E & & $<36$ weeks & $40 \%$ & $100 \%$ & $100 \%$ & $69 \%$ \\
\hline Crane et al., $1997^{29}$ & 162 & $30 \mathrm{~mm}$ & $23-33$ & B,C,D & $\mathrm{F}_{2}, \mathrm{G}, \mathrm{H}, \mathrm{I}$ & $<37$ weeks & $33 \%$ & $81 \%$ & $90 \%$ & $46 \%$ \\
\hline Cetin et al., $1997^{28}$ & 57 & $30 \mathrm{~mm}$ & $26-35$ & A,B,C,D,E & $\mathrm{F}_{3}, \mathrm{H}$ & recurrent PTL & $43 \%$ & $100 \%$ & $100 \%$ & $58 \%$ \\
\hline Venditelli et al., $2000^{30}$ & 200 & $30 \mathrm{~mm}$ & $18-36$ & B & $\mathrm{F}_{2}, \mathrm{G}, \mathrm{J}$ & $<37$ weeks & $41 \%$ & $83 \%$ & $81 \%$ & $54 \%$ \\
\hline Hincz et al.,2002 ${ }^{31}$ & 82 & $32 \mathrm{~mm}$ & $24-34$ & A,B,C & $\mathrm{F}_{2}, \mathrm{G}, \mathrm{H}$ & within 4 weeks & $17 \%$ & $100 \%$ & $100 \%$ & $28 \%$ \\
\hline Daskalakis et al., $2005^{32}$ & 172 & $30 \mathrm{~mm}$ & $24-34$ & A,B,C,D & $F_{2}, G$ & $<34$ weeks & $37 \%$ & $100 \%$ & $100 \%$ & $64 \%$ \\
\hline $\begin{array}{l}\text { Gomez et al., } 2005^{33} \\
\text { subgroup week 22-31 }\end{array}$ & $\begin{array}{l}215 \\
101\end{array}$ & $30 \mathrm{~mm}$ & $\begin{array}{l}22-35 \\
22-32\end{array}$ & A,B & F2 & $\begin{array}{l}<36 \text { weeks } \\
<33 \text { weeks }\end{array}$ & $\begin{array}{r}16 \% \\
9 \%\end{array}$ & $\begin{array}{r}88 \% \\
100 \%\end{array}$ & $\begin{array}{r}96 \% \\
100 \%\end{array}$ & $\begin{array}{l}28 \% \\
18 \%\end{array}$ \\
\hline Schmitz et al., $2006^{34}$ & 359 & $31 \mathrm{~mm}$ & $18-34$ & A,B & $\mathrm{F}_{2}, \mathrm{G}, \mathrm{H}$ & $<35$ weeks & $13 \%$ & $90 \%$ & $97 \%$ & $20 \%$ \\
\hline Önderglou et al., $1997^{16}$ & 90 & $29 \mathrm{~mm}$ & $25-36$ & A,B & $\mathrm{F}_{2}, \mathrm{H}$ & $<37$ weeks & $36 \%$ & $78 \%$ & $87 \%$ & $71 \%$ \\
\hline Volumenie et al., $2004^{18}$ & 59 & $28 \mathrm{~mm}$ & $18-34$ & $A, C$ & $\mathrm{~F}_{2}, \mathrm{H}$ & $<37$ weeks & $39 \%$ & $70 \%$ & $77 \%$ & $55 \%$ \\
\hline Rozenberg et al., $1997^{35}$ & 76 & $27 \mathrm{~mm}$ & $24-34$ & A,B,C & $\mathrm{F}_{1}, \mathrm{H}$ & $<37$ weeks & $26 \%$ & $75 \%$ & $89 \%$ & $50 \%$ \\
\hline Tekesin et al., $2003^{17}$ & 68 & $26 \mathrm{~mm}$ & $20-35$ & $\mathrm{~A}, \mathrm{~B}, \mathrm{C}$ & & $<37$ weeks & $41 \%$ & $82 \%$ & $83 \%$ & $62 \%$ \\
\hline Fuchs et al., $2004^{36}$ & 87 & $26 \mathrm{~mm}$ & $24-36$ & twins, $B_{2}$. & $\mathrm{F}_{2}$ & within 1 week & $22 \%$ & $100 \%$ & $100 \%$ & $29 \%$ \\
\hline Tsoi et al., $2005^{37}$ & 510 & $21 \mathrm{~mm}$ & $24-34$ & A,B. & $\mathrm{F}_{2}$ & $<35$ weeks & $15 \%$ & $78 \%$ & $95 \%$ & $35 \%$ \\
\hline Rizzo et al., $1996^{38}$ & 108 & $21 \mathrm{~mm}$ & $24-36$ & A,B & $\mathrm{F}_{2}$ & $<37$ weeks & $44 \%$ & $68 \%$ & $76 \%$ & $71 \%$ \\
\hline Gomez et al., $1994^{19}$ & 59 & $19 \mathrm{~mm}$ & $20-35$ & $A, C$ & $\mathrm{~F}_{2}$ & $<36$ weeks & $37 \%$ & $73 \%$ & $83 \%$ & $67 \%$ \\
\hline $\begin{array}{l}\text { Fuchs et al., } 2004^{39} \\
\text { subgroup weeks } 24-31\end{array}$ & $\begin{array}{l}253 \\
162\end{array}$ & $15 \mathrm{~mm}$ & $\begin{array}{l}24-35 \\
24-31\end{array}$ & $\mathrm{~A}, \mathrm{~B}_{2}$ & $\mathrm{~F}_{2}$ & within 1 week & $\begin{array}{l}8 \% \\
7 \%\end{array}$ & $\begin{array}{l}81 \% \\
75 \%\end{array}$ & $\begin{array}{l}98 \% \\
98 \%\end{array}$ & $\begin{array}{l}47 \% \\
47 \%\end{array}$ \\
\hline Tsoi et al., $2003^{40}$ & 216 & $15 \mathrm{~mm}$ & $24-36$ & $\mathrm{~A}, \mathrm{~B}_{2}$ & $\mathrm{~F}_{2}$ & within 1 week & $8 \%$ & $94 \%$ & $99 \%$ & $37 \%$ \\
\hline Tsoi et al., $2004^{41}$ & 63 & $15 \mathrm{~mm}$ & $24-36$ & $\mathrm{~A}, \mathrm{~B}_{2}$ & $\mathrm{~F}_{2}$ & within 1 week & $32 \%$ & $100 \%$ & $100 \%$ & $67 \%$ \\
\hline $\begin{array}{l}\text { * Inclusion criteria: } \\
\mathrm{A}=\text { Singletons only } \\
\mathrm{B}=\text { Regular contractions } \\
\mathrm{B}_{2}=\text { Regular painful contractions } \\
\mathrm{C}=\text { Cervical affection at palpation } \\
\mathrm{D}=\text { Tocolytic treatment } \\
\mathrm{E}=\text { Successful tocolysis }\end{array}$ & & & $\begin{array}{l}* * \text { Exclusior } \\
\mathrm{F}_{1}=\text { Cervica } \\
\mathrm{F}_{2}=\text { Cervica } \\
\mathrm{F}_{3}=\text { Cervica } \\
\mathrm{G}=\text { Vaginal } \\
\mathrm{H}=\text { Other } \mathrm{m} \\
\mathrm{I}=\text { Diagnos } \\
\mathrm{J}=\text { Birth wit }\end{array}$ & $\begin{array}{l}\text { criteria: } \\
\text { dilation } \geq 2 \mathrm{~cm} \\
\text { dilation }>3 \mathrm{~cm} \text { or } \geq 3 \mathrm{~cm} \\
\text { dilation }>5 \mathrm{~cm} \\
\text { leeding } \\
\text { ain pregnancy complications } \\
\text { PTL not in doubt } \\
\text { in 24h }\end{array}$ & & & & & & \\
\hline
\end{tabular}


Table 2. Symptoms and signs at admission in 115 women with singleton pregnancy hospitalised for threatened preterm birth before 27 weeks, in relation to gestational age at delivery.

$\begin{array}{rrr}\text { Birth before } & \begin{array}{r}\text { Birth after } \\ 32 \text { weeks }\end{array} & \text { P value } \\ \text { 32weeks } & & \\ & \end{array}$

Background data and treatment

Primiparous, $n$ (\%)

Previous preterm birth or late ab
Hospital stay (before delivery),

days, median (range)

Tocolytic infusion therapy n (\%)

$\begin{array}{rrr}33(50 \%) & 23(47 \%) & \\ 17(26 \%) & 9(18 \%) & \\ & & \\ 4(1-39) & 2(1-32) & \mathrm{p}<0.01 \\ 50(76 \%) & 15(31 \%) & \mathrm{p}<0.01\end{array}$

Symptoms noted at admission, $\mathbf{n}(\%)$

Regular contractions

$32(48 \%)$

$22(45 \%)$

Painful contractions

$28(42 \%)$

$13(28 \%)$

Low abdominal pain or menstrual ache

$21(32 \%)$

$23(47 \%)$

$8(10 \%)$

$6(18 \%)$

Backache

$40(61 \%)$

$6(13 \%)$

$14(22 \%)$

$2(3 \%)$

$7(15 \%)$

Vaginal discharge

Fever

Duration of symptoms less than a day

$34(54 \%)$

18 (39\%)

Signs at admission, $\mathbf{n}(\%)$

Palpation and speculum examination:

Effaced cervix

$42 \frac{N=64}{(66 \%)}$

$41(64 \%)$

$\underline{N=49}$

Cervical dilation $\geq 2 \mathrm{~cm}$

$41(64 \%)$

$2(3 \%)$

$3(6 \%)$

$\mathrm{p}<0.01$

Bulging membranes

Presenting part on pelvic floor

$N=24$

$11(46 \%)$

$6(25 \%)$

$4(17 \%)$

$3(12 \%)$

$2(4 \%)$

$\mathrm{p}<0.01$

Ultrasonography:

Cervical length $<5 \mathrm{~mm}$

5-20 mm

20-29 mm

$\geq 30 \mathrm{~mm}$

$\underline{N=65}$

$14 \overline{(22 \%)}$

$9(14 \%)$

$7(11 \%)$

$N=\frac{21}{0}$

$4(19 \%)$

$2(10 \%)$

$15(71 \%)$

$\mathrm{p}<0.01$

$C$-reactive protein (CRP):

$<10 \mathrm{mg} / \mathrm{L}$

$10-14 \mathrm{mg} / \mathrm{L}$

$26(40 \%)$

$\begin{array}{rr}\frac{N=47}{(66 \%)} & \mathrm{p}<0.01 \\ 7(15 \%) & \\ 3(6 \%) & \\ 1(2 \%) & \mathrm{p}<0.01\end{array}$ 
Table 3. Rates of spontaneous preterm birth (after spontaneous labour or rupture of the membranes) in women living in the primary uptake area delivered at Lund University Hospital between June $1^{\text {st }} 2001$ and August $31^{\text {st }} 2005$, with and without registered outpatient visits for preterm labour during January $1^{\text {st }} 2001$ and August $31^{\text {st }} 2005$.

\begin{tabular}{|c|c|c|c|c|c|c|c|}
\hline & $\begin{array}{r}\text { All } \\
\mathrm{N}=11,406\end{array}$ & $\begin{array}{r}\text { No visit } \\
\mathrm{N}=10,898\end{array}$ & $\begin{array}{r}\text { Any visit be- } \\
\text { fore } 37 \text { weeks } \\
\mathrm{N}=503\end{array}$ & $\begin{array}{r}\text { Visit before } \\
22 \text { weeks } \\
N=43\end{array}$ & $\begin{array}{r}\text { Visit during } \\
\text { week } 22-26 \\
\mathrm{~N}=132\end{array}$ & $\begin{array}{r}\text { Visit during } \\
\text { week } 27-31 \\
\mathrm{~N}=133\end{array}$ & $\begin{array}{r}\text { Visit during } \\
\text { week 32-36 } \\
\mathrm{N}=197\end{array}$ \\
\hline $\begin{array}{l}\text { Spontaneous birth before } 37 \text { weeks } \\
P \text { (compared to patients with no visit) }\end{array}$ & 525 (4.6\%) & 487 (4.5\%) & $\begin{array}{r}38(7.6 \%) \\
0.001\end{array}$ & $\begin{array}{r}2(4.7 \%) \\
0.95\end{array}$ & $\begin{array}{r}10(7.6 \%) \\
0.09\end{array}$ & $\begin{array}{r}9(6.8 \%) \\
0.22\end{array}$ & $\begin{array}{r}17(8.6 \%) \\
0.005\end{array}$ \\
\hline $\begin{array}{l}\text { Spontaneous birth before } 32 \text { weeks } \\
P \text { (compared to patients with no visit) }\end{array}$ & $62(0.54 \%)$ & 59 (0.5\%) & $\begin{array}{r}3(0.6 \%) \\
0.87\end{array}$ & $\begin{array}{l}0 \\
-\end{array}$ & $1(0.8 \%)$ & $2(1.5 \%)$ & - \\
\hline $\begin{array}{l}\text { Spontaneous birth before } 27 \text { weeks } \\
P \text { (compared to patients with no visit) }\end{array}$ & $14(0.12 \%)$ & $13(0.1 \%)$ & $\begin{array}{r}1(0.2 \%) \\
0.62\end{array}$ & $\begin{array}{l}0 \\
-\end{array}$ & $1(0.8 \%)$ & $\begin{array}{l}- \\
-\end{array}$ & - \\
\hline
\end{tabular}

